\title{
Landlady's daughter: competition
}

Richard Asher, in Talking Sense, suggests that, if you want to get something really clear in your mind, you should try to explain it to your landlady's daughter. The idea is that if you can explain it in "very simple terms ... the process of so reducing it is helpful." We can take it that Asher's landlady's daughter was not likely to be a research student in the social sciences, those being different times.

Asher goes on to give an example of this type of exercise: "I was given a book to review some years ago, which contained this sentence: 'A significant fact about our personality is that...- " and the quote goes on in a majesty of loquacity that would make you tremble.

This Asher reduces, with his eye firmly on his landlady's daughter, to "We know what is us, and what isn't," which has all the appeal of a squashed meringue.

The object of this competition is to restore this vulgar summary to its former polysyllabic glory. Entries will be judged on a syllable count, although deductions will be made for frank repetition or deviation.

A Gaskell book and a College mug will be awarded to the entry with the most syllables. The original prose and the winner will be given in the April 1993 issue, and entries have to be sent to the Psychiatric Bulletin by 31 January 1993.

\section{Reference}

AsHER, R. (1972) Talking Sense. London: Pitman Medical.

\section{Miscellany}

\section{Appointment}

Dr John H. Henderson, formerly Medical Director and Consultant Psychiatrist at St Andrew's Hospital, Northampton, has been appointed as the director of the Mental Health Foundation's grants and projects division.

\section{Awards}

The Stanley Research Awards are part of a broad Stanley Foundation Research Program begun in 1989 to support research on the causes and treatment of serious mental illnesses and are intended to attract established scientists from other areas of biology and medicine (e.g. biochemistry and neurology) into research on mental illnesses as well as to provide support for innovative research by established scientists already in the field but whose funding sources are limited. Further information: Ms Kelly D. Peck, Stanley Foundation Research Awards Programs, c/o NAMI, 2101 Wilson Blvd., Suite 302, Arlington, VA 22201, USA.

Dr Lars Farde of Karolinska Institute in Stockholm, Sweden is winner of the 1992 Max Hamilton Memorial Award for his contributions to the field of psychopharmacology including pioneering the use of Positron
Emission Tomography (PET) for the study of receptor binding.

\section{New publications}

Liverpool District Psychiatric Audit Committee have recently published their first Audit Newsletter which sets out the activity undertaken since formal monthly audit meetings began in February 1991. All medical staff working in the psychiatric within the Liverpool district participate. Summary findings from case-note reviews conducted at the meetings are included in the Newsletter. The current contents of an audit database of relevance to mental health is also included. Copies of the Newsletter are available from: Dr I.A. Davidson, Chairman, Liverpool District Psychiatry Audit Committee, Acute Directorate, Arundel House, Community Mental Health Resource Centre, Sefton General Hospital, Smithdown Road, Liverpool L15 2HE.

Education in Action is a new guide published by the education department of the charity Community Service Volunteers (CSV) and gives an introduction to some of the charity's publications aimed at those in the health care field. Copies can be obtained from: The Executive Officer, CSV Education, 237 Pentonville Road, London N1 9NJ. 